\title{
A Numerical Example Illustrating Cost of Idle Capacity in Manufacturing
}

\author{
Gerald Aranoff \\ Ariel University Center of Samaria, Bnei Brak, Israel \\ Email: garanoff@netvision.net.il
}

Received 13 October 2014; revised 16 November 2014; accepted 5 December 2014

Copyright (C) 2014 by author and Scientific Research Publishing Inc.

This work is licensed under the Creative Commons Attribution International License (CC BY). http://creativecommons.org/licenses/by/4.0/

(c) (i) Open Access

\begin{abstract}
We present an elaborate numerical example of a competitive manufacturing industry in the United States facing demand fluctuations to illustrate cost of idle capacity in manufacturing. We show that given demand fluctuations, such as the business cycle, significant cost of idle capacity is not only ordinary and necessary but desirable! We recommend manufacturing firms in the United States increase outsourcing major parts and components to increase output-rates flexibility. Outsourcing is rising in recent years with advances in internet, computers, and telephone. Manufacturers today can depend on getting needed parts "just-in-time" from outside suppliers without maintaining inventories of parts or capacity to produce parts.
\end{abstract}

\section{Keywords}

Production, Cost, Capacity, Business Cycle, Output-Rate Flexibility

\section{John M. Clark: The Economics of Overhead Costs}

John M. Clark (1884-1963) wrote of the desirability of manufacturing plants to operate at their normal capacity with production costs per-unit output the lowest. John M. Clark attributed the main problems of the business cycle to the dominant role of fixed costs that are incurred irrespective of output rates:

"It is needless to point out that overhead costs play a fundamental part in the behavior of business at every stage of that many-sided phenomenon, the business cycle. The part they play is most paradoxical. For they make regular operation peculiarly desirable and peculiarly profitable, so that business feels a definite loss whenever output falls below normal capacity, yet it is largely due to this very fact of large fixed capital that business breads these calamities for itself, out of the laws of its own being. And the largest businesses, which have the highest percent of constant costs due to invested capital, are, as we have seen, precisely the ones which fluctuate the most, so far as employment is an index. There is something about the commercial-industrial system which 
bewitches business so that it does just the thing it is trying to avoid, and is held back from doing just the thing it yearns to do-maintain steady operation and avoid idle overhead. And while the contributing causes of this strange auto-hypnosis are many and of varied character, technical, financial, commercial, and psychological; the underlying fact of large capital plays a central part, and the inelasticity of costs, sunk costs, and the shifting and conversion of overhead costs are all facts of major importance" $[1]^{1}$.

\section{Recent Articles on Manufacturing Idle-Capacity Costs}

In our Cost Management March/April 2011 article [2] we argued, referring to Baxendale-Foster Cost Management September/October 2010 article [3]:

"John M. Clark taught us to expect productive capacity to exceed average demand as a normal and desirable situation, due to irregularity of demand and inelasticity of supply. This produces idle capacity as a normal and desirable situation for much of the time. John M. Clark advocated cost accountants to isolate cost of idle capacity from cost of producing goods. Sopariwala and Baxendale-Foster do this in their illustrated example. Baxendale-Foster showing cost of idle capacity by activity is an important refinement over Sopariwala, who shows just the total idle capacity to the firm. Baxendale-Foster has a good discussion, showing the importance of isolating cost of idle capacity. We can hope cost-accountants will do as Baxendale-Foster illustrates: use ABC costing and isolate cost of idle capacity by activity. Idle-Capacity Costs in ABC Absorption and Direct-Costing Income Statements we praised the Baxendale-Foster proposal to show idle-capacity cost in manufacturing by activity".

In our Cost Management May/June 2011 article [4] we stated:

"I made the percent calculations using Clark's probable total economic cost of the car as the base. Cost of idle capacity at 12.8 percent is clearly a significant cost factor and must be carefully planned and controlled. Clark, in 1923, gave us a detailed illustration that today we can learn much from on the proper way to make its calculation. A firm needs both an economist and an accountant to provide the necessary information to calculate this cost element. An economist would make the discrete estimates of output rates and their likelihoods. An accountant would prepare flexible-budget amounts on an annual basis for each of the output rates projected. The accountant and the economist would then examine alternative scenarios using spread-sheet analysis. The fundamental calculation of the cost of idle capacity should be as Clark did it in 1923".

In Herath H. B. and Kusy, M. I. Cost Management September/October 2014 [5] they note with approval:

"Aranoff proposes a further refinement to consider activity capacity constraints to separate the cost of idle capacity in Baxendale and Foster and Sopariwala into excess capacity cost and idle-capacity cost. Excess capacity of an activity is the limit placed on the usage of available capacity due to the constraint imposed by another activity in a production process. Idle capacity, then, is the under-utilization of each activity's capacity compared to the constraining activity. The caveat in the above articles is the importance of considering the cost of idle capacity in determining the economic cost for pricing and efficient management of operations".

\section{The US Cement Industry: A Competitive Manufacturing Industry}

This paper is an outgrowth of my study on the US cement industry [6]. The US cement industry has, approximately, the restrictive assumptions of the theoretical model of this paper: single-homogeneous product that is costly to store over the business cycle, competitive manufacturing, linear-total-costs with capacity limits, alternative technologies available, durable and specific assets, and reactivation of semi-obsolete plants during economic peaks.

\section{Manufacturing Cement over a Business Cycle: The Supply Side}

We assume a single-homogeneous product, $Q$, cement. We assume ease of entry of new cement manufacturers. We assume a business cycle of two states of demand, $D_{1} w_{1}$ and $D_{2} w_{2}$, off-peak and peak, each with a likelihood, where the likelihoods add to one. Cement-manufacturing plants require durable and specific assets, and have linear short-run total-cost curves with absolute capacity limits. There are two types of cement-manufacturing plants, plant $K_{K}$ and plant $_{L}$, each having linear total costs with absolute capacity limits. Cement-manufacturing plants have a per-ton cement variable cost $V C$ made up of direct materials, direct labor, and variable factory

${ }^{1}$ John M. Clark, 1923, page 386. 
overhead; per-ton cement fixed-factory-overhead costs FFOH (fixed factory overhead per-year per-plant divided by maximum cement production rate per-year per-plant) and per-plant capacity $q$ (maximum cement production per-year per-plant).

We envision investors and managers walking into a cement manufacturing plant store that has two shelves: each with a model plant that costs, say, $\$ 1,000,000$ to build. On one shelf is a model of plant $K_{K}$ and on the other shelf is a model plant ${ }_{L}$ (see Figure 1).

Investors or entrepreneurs can order any multiple or fraction of the model plants. No economies of scale exist for plants. Thus the long-run marginal cost (LRMC) and long-run average cost (LRAC) for plants in the cementmanufacturing plant store are horizontal. These customers of the cement-manufacturing plant store have to decide technology $y_{K}$ or technology $y_{L}$ and then choose the plant size (or the number of plants). The assets are durable and specific meaning that the plants will last a long time, say 50 years, and are useful only for making cement.

\section{Cement over the Business Cycle: The Demand Side}

There are two groups in our hypothetical society: Producers (manufacturers of cement) and consumers (households who buy cement). Consumers buy cement in a free market on a daily basis from various manufacturers where each manufacturer posts its prices. Consumers pay the lowest price per-ton cement in the local market. The intersection of this price with the consumer demand schedules (off-peak and peak) determine the quantity of cement the consumers order. Consumers pay market price times quantities purchased, $T R=P \times Q$ (total revenue to suppliers equals market price times quantities).

\section{The Numerical Example}

Investors that go the cement manufacturing store decide on technology $y_{K}$ or technology $y_{L}$ and then on the plant size which is given by $n$ the number of plants. Fractional size plants are permitted. $n_{K}=1$ means that capacity is 0.72 tons per cycle and $n_{L}=1$ means that capacity is 0.90 tons per cycle. This follows Figure $1 . V C_{K}=\$ 24$ per ton while $V C_{L}=\$ 31.20$ per ton as in Figure 1. $F F O H_{K}=\$ 12.00$ per ton while $F F O H_{L}=\$ 4.80$ per ton as in Figure 1. The short-run average (SAC) curve falls as output increases and reaches a minimum at $\mathrm{VC}+\mathrm{FFOH}$.

In the numerical example, shown in Table $1, S A C(\min )_{K}=S A C(\min )_{L}=\$ 36$ per ton for simplification. This makes technology $y_{L}$ dominate since if investors only seek profits they would choose only technology $y_{L}$. Technology $y_{L}$ relies on outsourcing which may a be drawback to some investors as outsourcing gives less direct control to managers. I argue elsewhere on conditions for indifference between technology choice $[7]^{2}$.

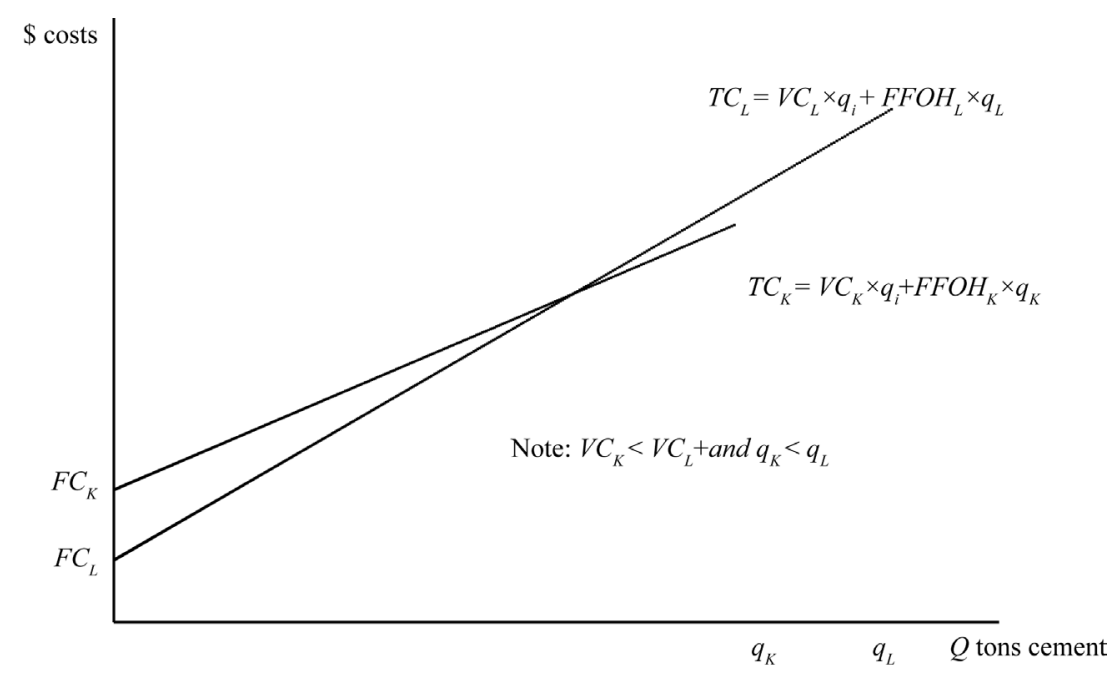

Figure 1. SR total-cost curves of Plant ${ }_{K}$ and Plant $_{L}$.

${ }^{2}$ Aranoff, G., "Competitive Manufacturing with Fluctuating Demand and Diverse Technology: Mathematical Proofs and Illuminations on Industry Output-Flexibility,” Economic Modelling 28 (2011) 1441-1450. 
Table 1. Numerical example.

\begin{tabular}{|c|c|c|c|}
\hline$T C_{K}=24 q_{i}+12 q_{K}$ & see Figure 1 & $T C_{L}=31.2 q_{i}+4.8 q_{L}$ & see Figure 1 \\
\hline$V C_{K}=$ & $\$ 24.00$ per ton & $V C_{L}=$ & $\$ 31.20$ per ton \\
\hline $\mathrm{FFOH}_{K}=$ & $\$ 12.00$ per ton & $\mathrm{FFOH}_{L}=$ & $\$ 4.80$ per ton \\
\hline$q_{K}=$ & 0.72 tons per cycle & $q_{L}=$ & 0.90 tons per cycle \\
\hline$F C_{K}=F F O H_{K} \times q_{K}=$ & $\$ 8.64$ per cycle & $F C_{L}=F_{F O H} \times q_{L}=$ & $\$ 4.32$ per cycle \\
\hline $\mathrm{SAC}(\min )_{K}=24+12=$ & \$36 per ton & $\mathrm{SAC}(\min )_{L}=31.2+1.8=$ & $\$ 36$ per ton \\
\hline Let $w_{1}=$ & 0.5 & Let $w_{2}=$ & 0.5 \\
\hline Let $P_{1}=$ & & Let $P_{2}=$ & \\
\hline$V C_{L}=$ & $\$ 31.20$ per ton & $V C_{L}+F F O H_{L} / w_{2}=$ & $\$ 40.80$ per ton \\
\hline Let $Q_{1}=1152 / P_{1}=$ & 36.92 tons per period & Let $Q_{2}=3456 / P_{2}=$ & 84.71 tons per period \\
\hline$n_{K}=Q_{1} / q_{K}=$ & 51.28 plants & $n_{L}=\left(Q_{2}-Q_{1}\right) / q_{L}$ & 53.09 plants \\
\hline$T R_{1}=P_{1} Q_{1}=$ & $\$ 1152$ & $T R_{2}=P_{2} Q_{2}=$ & $\$ 3456$ \\
\hline$E(Q)=w_{1} Q_{1}+w_{2} Q_{2}$ & 60.81 & tons & \\
\hline$E(T R)=w_{1} Q_{1} P_{1}+w_{2} Q_{2} P_{2}=$ & $\$ 2304$ & & \\
\hline$E(V C)=V C_{K} Q_{1}+V C_{L}\left(Q_{2}-Q_{1}\right) w_{2}=$ & $\$ 1632$ & & \\
\hline$E(F C)=F F O H_{K} Q_{1}+F F O H_{L}\left(Q_{2}-Q_{1}\right)=$ & $\$ 672$ & & \\
\hline$E(\pi)=E(T R)-E(V C)-E(F C)=$ & $\$ 0$ & LR equilibrium & \\
\hline$E(A C)=E(T C) / E(Q)=$ & $\$ 37.89$ & per ton & \\
\hline \multicolumn{4}{|l|}{ Cost of idle capacity = } \\
\hline$E(A C)-S A C(\min )=$ & $\$ 1.89$ & per ton & \\
\hline \multicolumn{4}{|l|}{ Proof of cost of idle capacity } \\
\hline$E(T C)$ of production $=\mathrm{E}(\mathrm{TR})=$ & $\$ 2304$ & & \\
\hline$E(T C)$ of production if always at $\mathrm{SAC}(\mathrm{min})=$ & $\$ 2189$ & & \\
\hline Excess production costs over $\mathrm{SAC}(\mathrm{min})=$ & $\$ 115$ & & \\
\hline Excess production costs $/ E(Q)=$ & $\$ 1.89$ & per ton & \\
\hline
\end{tabular}

We assume $w_{1}=w_{2}=0.5$ and $Q_{1}=1152 / P_{1}$ and $Q_{2}=3456 / P_{2}$ to simplify the numerical example. We

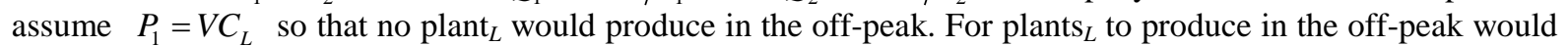
require $P_{1}>V C_{L}$. We assume $P_{2}=V C_{L}+F F O H_{L} / w_{2}$ so that plant $L_{L}$ would have $\$ 0$ LR equilibrium profits.

We can prove $\$ 0$ LR equilibrium profits to both plants ${ }_{K}$ and plants $_{L}$ by imagining each plant has capacity 1 ton per period. Plant ${ }_{K}$ produces at its SAC $(\mathrm{min})=\$ 36$ per ton in each period and so needs revenues for 1 ton produced in each period of $P_{1}+P_{2}=\$ 31.20+\$ 40.80=\$ 72$ for the sum of the two periods. Plant $L_{L}$ shuts down temporarily in the off-peak. In the peak $P_{2}=V C_{L}+F F O H_{L} / w_{2}=\$ 40.80$ per ton which exactly covers the $\mathrm{VC}_{L}$ in the peak time and the $\mathrm{FFOH}_{L}$ in both periods.

The $\mathrm{E}(\mathrm{AC})$ of a ton of cement in the industry $=\$ 37.89$. With the $\mathrm{SAC}(\mathrm{min})=\$ 36$ per ton the cost of idle capacity $=\$ 37.89-\$ 36=\$ 1.89$ per ton.

\section{Some Insights}

In the numerical example, the cost of idle capacity $=\$ 37.89-\$ 36=\$ 1.89$. The numerical example uses simple numbers to make the points. The numerical example has rigid assumptions that we feel are fairly realistic and reasonable today in much of manufacturing: no economies of scale, easy entry, demand fluctuations, linear SRTC production functions with capacity limits, and durable and specific assets.

One novelty here is the choice firms have in plants or plants $_{L}$. The assumption is that firms will choose plants $_{K}$ to produce the minimum needed over the cycle and plants $s_{L}$ to produce excess demand over the minimum. 
Table 2. \% capacity utilization manufacturing USA.

\begin{tabular}{ccccccc}
\hline $1972-2013$ Avg & $1988-1989$ High & $1990-1991$ Low & $1994-1995$ High & 2009 Low & 2013 Oct. & 2014 Oct. \\
\hline 78.7 & 85.6 & 77.3 & 84.6 & 63.9 & 76.3 & 77.2 \\
\hline
\end{tabular}

Clark wrote of firms keeping old-inefficient plant and equipment for part-time use in high-demand times, to serve only as stand-by units $[8]^{3}$. A realistic assumption today is that plants $s_{L}$ rely heavily on outsourcing of major components and parts. Outsourcing is rising in recent years with advances in internet, computers, and telephone. Manufacturers today can depend on getting needed parts "just-in-time" from outside suppliers without maintaining inventories of parts or capacity to produce parts ${ }^{4}$.

Plants $_{K}$ always operate at their SAC (min), thus the cost of idle capacity of $\$ 1.89$ per ton is due entirely to plants $_{L}$ shutting down in the off-peak. Plants $s_{L}$ shutting down in the off peak is good. During a recession, there is little benefit from all plants operating, especially with a semi-perishable and costly to store product such as cement. Investors should choose to invest in plants ${ }_{K}$ only if they expect to operate at capacity at all times.

United States manufacturing industries are now some 6 or 7 years in a recession, as the statistical releases of the USA Federal Reserve in Table 2 show $^{5}$.

According to the model here, during recessions investors should choose to invest in plants ${ }_{L}$, with the aim of profiting with the return of peak-demand times. To make policy recommendations, we need research on how realistic and critical are the assumptions of the model.

\section{References}

[1] Clark, J.M. (1923) Studies in the Economics of Overhead Costs. The University of Chicago Press, Chicago.

[2] Aranoff, G. (2011) Idle-Capacity Costs in ABC Absorption and Direct-Costing Income Statements. Cost Management, 25(2), 6-10.

[3] Baxendale, S.J. and Foster, B.P. (2010) ABC Absorption and Direct Costing Income Statement. Cost Management, 24(5), 5-14.

[4] Aranoff, G. (2011) John M. Clark’s Calculation of Cost of Idle Capacity. Cost Management, 25(3), 25-32.

[5] Herath, H.B. and Kusy, M.I. (2014) Activity-Based Costing: Potential Research Issues on the Choice of Cost Management Systems. Cost Management, 28(5), 5-22.

[6] Aranoff, G. (1991) John M. Clark’s Concept of Too Strong Competition and a Possible Case: The US Cement Industry. Eastern Economic Journal, 17(1), 45-60.

[7] Aranoff, G. (2011) Competitive Manufacturing with Fluctuating Demand and Diverse Technology: Mathematical Proofs and Illuminations on Industry Output-Flexibility. Economic Modelling, 28, 1441-1450. http://dx.doi.org/10.1016/i.econmod.2011.02.016

[8] Clark, J.M. (1961) Competition as a Dynamic Process. The Brookings Institution, Washington DC.

\footnotetext{
${ }^{3}$ John M. Clark, 1961, page 137.

${ }^{4}$ An example where firms today are recognizing the advantages of relying heavily on outsourcing in manufacturing is the Reuters November 2014 item “Airbus Emulates Carmakers to Drive Jet Output”.

${ }^{5}$ Source: www.federalreserve.gov/releases/.
} 
Scientific Research Publishing (SCIRP) is one of the largest Open Access journal publishers. It is currently publishing more than 200 open access, online, peer-reviewed journals covering a wide range of academic disciplines. SCIRP serves the worldwide academic communities and contributes to the progress and application of science with its publication.

Other selected journals from SCIRP are listed as below. Submit your manuscript to us via either submit@scirp.org or Online Submission Portal.
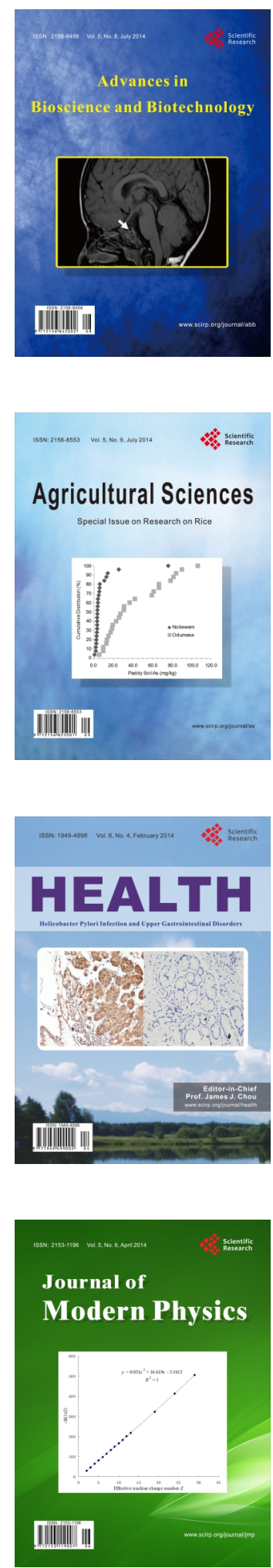
